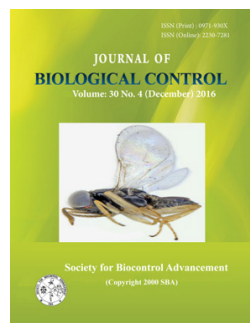

\title{
Recent trends in biological control of scale insects on fruit crops in India
}

\author{
M. MANI* \\ Former Head, Division of Entomology, Nematology, Indian Institute of Horticultural Research, \\ Bangalore - 560 089, Karnataka, India \\ *Corresponding author E-mail: mmani1949@yahoo.co.in
}

\begin{abstract}
Scale insects are sap feeders, causing threat to the cultivation of several fruit crops. The scale insects can be grouped into two broad categories. The first group belonging to family Diaspidide, comprises many species of armoured scales (hard scales) belonging to the genera. Aonidiella, Aulacaspis, Pseudaulacaspis, Hemiberlesia, Aspidiotus, Chrysomphalus, Pinnaspis, Parlatoria etc. The second category belonging to family Coccidae comprises of the soft scales belonging to the genera Coccus, Puvinaria, Chloropulvinaria, Saisettia, Parasaisettia, Vinsonia, Drephanococcus, Ceroplastes, Ceroplastodes, etc. Scale insects are highly polyphagous, but certain species cause severe damage to specific fruit crops viz. the red scale, Aonidiella aurantii (Maskell) on citrus; latania scale, Hemieberlesia lataniae (Sign.) on grapevine.; white scale, Aulacaspis tubercularis (Newstead) on mango; green shield scale, Pulvinaria psidii (Maskell) on guava, lemon and sapota, Pulvinaria polygonata (Ckll.) on mango; green scale Coccus viridis (Green) on citrus and sapota and Drephanococcus chiton (Green) on ber and guava. Insecticides are not effective due to the presence of protective cover over the scales. On the other hand, scale insects are more amenable for biological control due to their sedentary habit and colonial distribution. Several scale insects are well regulated by the local predators. In nature, green shield scale, Pulvinaria psidii (Maskell) is kept under check by the predator, Australian ladybird beetle Cryptolaemus montouzieri Mulsant on guava, sapota and lemon. The reduction of the mango green shield scale Pulvinaria polygonata was attributed mainly to the action of the predators C. montrouzieri and Spalgis epeus Westwood. The green scale Coccus viridis on acid lime and white scale Aulacaspis tubercularis on mango are well regulated by the coccinellids Chilocorus nigrita (Fab) and C. circumdatus Sch. Local parasitoids are also known to effectively check the populations of the scale insects on different fruit crops. The encyrtid Anicetus ceylonensis How and the pteromalid Cephaleta brunniventris Motsch are responsible for the suppression of wax scale Drephanococcus chiton on ber and guava. The aphelinid parasitoid, Pteroptrix koebeli How. plays a major role in the regulation of the mango scale Aulacaspis tubercularis. On sapota, the aphelinid parasitoid Coccophagus sp. was the dominant natural enemy causing up to $95 \%$ parasitism. Scutellista cyanea Motsch. (Pteromalidiae: Hymenoptera) was able to suppress Parasaissetia nigra (Nietner) on custard apple and pomegranate. In the absence of effective biocontrol agents in nature, parasitoids and predators have to be released in the field for obtaining an effective and quicker suppression of the scale insects. Release of adult $C$. nigirita was found to be effective in the control of the red scale on citrus in Karnataka, Andhra Pradesh and Punjab. Release of C. infernalis (C.bijugus) Mulsant @ 10-20 beetles/tree once in April-May has also been recommended to reduce Sanjose scale. The white halo fungus, Lecanicillium (Verticillium) lecanii can be sprayed at $16 \times 10^{6}$ spores $/ \mathrm{ml}$ along with $0.05 \%$ of sticking agents in the evening hours at 15 days interval to control the green scale in the hilly areas during cooler months. The biocontrol agents can be integrated with plant origin insecticides as they do not affect the activity of these agents.
\end{abstract}

KEY WORDS: Biological control, fruit crops, hard scales, predator, parasitoids, scale insects, soft scales

(Article chronicle: 22-12-2016; Revised: 28-12-2016; Accepted: 28-12-2016)

\section{INTRODUCTION}

Scale insects get their name because the females secrete a waxy covering that gives them the appearance of a fish scale. They are tiny insects varying in colour. Scale insects are a diverse group of insects in the order Hemiptera, superfamily coccoidea. Scale insects can be broadly divided into two groups: armored scales (Diapididae) and soft scales (Coccidae). Armoured scales secrete a protective cover over their bodies. The soft scales are usually half round rubbery and are usually larger, lack the protective cover, but protect themselves with waxy secretions. Scale insects are sucking insects laying their the eggs underneath the hard scale covering or in an ovisac covered with filamentous secretion, making difficult to get killed with conventional chemicals (Maniand Krishnamoorthy, 2001). Nymphs and adult female scale insects become immobile/sedentary/sessile. They are easily available /susceptible throughout the year to the attack by the parasitoids and predators. In fact, the first 
outstanding biocontrol success was the complete suppression of the cottony cushion scale Icerya purchasi Maskell with the predator Rodolia cardinalis Mulsant was on citrus fruits ((Bartlett, 1978).

\section{Hard scales (Armoured Scale Insects, Diaspine scales)}

Armoured scales are formed from the waxy filaments that the insect secretes as it rotates its body in a circular pattern. Armoured scales are the smallest of scale insects, ranging in size from 1 to $3 \mathrm{~mm}$. The body of the scale insect is protected by a cover (the armour) made from wax secreted by the insect and cast skins (exuviae) of previous growth stages. The exposed body usually is yellow or orange, but may have a pink or red colour to it. This cover also protects the eggs laid by the female. Adult armored scales are usually protected from chemicals because of their protective shell (Rosen, 1990). The hard scales belonging to family Diaspidide, comprises many species belonging to the genera viz. Aonidiella, Aulacaspis, Pseudaulacaspis, Hemiberlesia, Aspidiotus, Chrysomphalus, Pinnaspis, Parlatoria etc. Among them, Calfornia red scale Aonidiella aurantii is found highly destructive to citrus in India causing heavy loss to citrus growers. San Jose scale - Quadraspidiotus perniciosus (Comstock) serious pest of many temperate fruits in Jammu \& Kashmir, Himachal Pradesh and Uttaranchal. Aulacaspis tubercularis and Aspidiotus destructor Signoret are well known to cause damage to mango. (Table 1)

\section{Biological control of diaspine/hard scales}

\section{San Jose Scale - Quadraspidiotus perniciosus}

Quadraspidiotus perniciosus (Comstock) is serious pest of many temperate fruits in Jammu \& Kashmir, Himachal Pradesh and Uttaranchal. The first signs of infestation include a decline of tree vigor, leaf drop and appearance of sparse yellow foliage, particularly on the terminal growth. Reddish spots on the underside of bark and around scales on leaves or fruit result from feeding of immature stages. In severe cases, the entire surface of bark can become covered with layers of overlapping grayish scales. Cracking and bleeding of limbs occur and heavily injured trees may die. The aphelinid parasitoid Encarsia perniciosi (Tower) was introduced in 1953 into India (Rao and Rao, 1960). The Russian strain of E. perniciosi proved satisfactory in H.P. while Chinese, American and Illinois strains performed much better in U.P. (Sahai and Joshi, 1965). In recent years, the pest has appeared in severe form mainly due to the interference of insecticidal applications. Augmentative release of E. perniciosi / Aphytis sp. (proclia group)/ Aphytis diaspidis (How.)@ 2,000 adults / infested tree once in spring is recommended to suppress the scale. Release of Aphytis sp. (proclia group) had resulted in 60-70\% parasitism in Kullu (H.P) (Thakur et al., 1989) and 40.2 \% in J\&K (Masoodi et al., 1989). Coccinellid predators Chilocorus infernalis Mulsant and Pharoscymnus flexibilis (Mulsant)

Table 1. List of hard scales infesting fruit crops in India

\begin{tabular}{|c|c|}
\hline Aonidiella citrina (Coquillett) & Citrus, custard apple, mango, date palm \\
\hline Aonidiella orientalis (Newstead) & Banana, ber, citrus, guava, jamun, peach, pomegranate, mango \\
\hline Aspidiotus destructor Signoret & $\begin{array}{l}\text { Banana, ber, citrus, guava, jamun, peach, pomegranate, fig, pear, } \\
\text { mango, sapota, apple, papaya, grapes }\end{array}$ \\
\hline Octaspidiotus tripurensis Takagi & Mango \\
\hline Aulacaspis tubercularis Newstead & Mango, citrus \\
\hline Chrysomphalus aonidum (L.) (= Chrysomphalus ficus Ashmead) & Citrus, mango, almond, banana, guava, grapes, date palm \\
\hline Chrysomphalus dictyosperni (Morgan) & Citrus, banana, mango, apple \\
\hline Hemiberlesia lataniae (Sign.) & $\begin{array}{l}\text { Apple, jack fruit, sapota, ber, grapes, plum, peach, citrus, ba- } \\
\text { nana, guava, mango }\end{array}$ \\
\hline Howardia biclavis (Comstock) & Sapota, peach, apple, ber, citrus, custard apple \\
\hline Lepidosaphes (=Corunaspis) beckii (Newman) & Citrus \\
\hline Parlatoria blanchardi (Targioni Tozzetti) & Date palm \\
\hline Parlatoria cinerea Hadden & Apple, apricot, citrus, phalsa, jamun, litchi, mango, peach, plum \\
\hline Parlatoria oleae (Colvée) & $\begin{array}{l}\text { Mango, ber, apricot, pomegranate, peach, apple, citrus, fig, } \\
\text { grapes, pear, plum, apple }\end{array}$ \\
\hline Purgatorial pergandii Comstock & Citrus, guava, mango \\
\hline Pinnaspis strachani Signoret & Date palm, citrus, banana \\
\hline Pinnaspis aspidistrae Signoret & Citrus, fig, jack fruit, mango \\
\hline $\begin{array}{l}\text { Pseudaulacaspis rubra (Maskell) (=Pseudaulacaspis bar- } \\
\text { beri (Green)) }\end{array}$ & Mango \\
\hline Pseudaulacaspis pentagona (Targioni) & Apple, cherry, peach, plum, pear \\
\hline Quadraspidiotus perniciosus (Comstock) & Apple, citrus, cherry, peach, plum, pear, raspberry, strawberry \\
\hline Chlidaspis asiatica (Archangelskaya) & Apple and plum \\
\hline
\end{tabular}


were found clearing the scales in Thanedhar areas of H. P. (Rawat et al., 1988). Release of C. infernalis (C.bijugus) Mulsant@10-20 beetles/tree once in April-May has also been recommended to reduce the scales (Singh, 2000).

\section{Aonidiella aurantii (California Red Scale /Citrus Red Scale)}

Aonidiella aurantii (Maskell) is an armoured scale insect with a circular, brownish-red cover. Scale insects of all ages feed by sucking sap. They are found on all parts of the plant but are most noticeable on the fruit. Heavy infestations may cause discoloration, shoot distortion and leaf drop. The fruit may become pitted and unmarketable. The tree's bark may split and the twigs and branches may die back and this sometimes results in the death of the tree. About 15 natural enemies were known to attack $A$. aurantii in India. Aphytis fisheri DeBach and Aphytis hispanicus (Mercet) at Gauhati, Assam (DeBach, 1959), Aphytis spp., Coccobius sp., Encarsia sp. and Pteroptrix koebeli (Howard) in Karnataka (CIBC, 1984), Chilocorus nigrita (Fab.), Scymnus quadrillum Motsch. (Pruthi and Mani, 1945), entomopathogenic fungus Attractium indica Chona and Munjal, Chilocorus circumdatus Sch. and C. hauseri Wse. (Rao, 1969) were reported on red scale. According to Krishnamoorthy (1993), Aphytis melinus Debach and A. linganensis Comp., A. fisheri Debach, Cybocephalus and Eryngiopus sp. were also known to attack the red scale. A. melinus when introduced into California from India had resulted in excellent control of the scale in citrus orchards. C. nigrita was the most voracious predator of $A$. aurantii. Release of adult beetles was found to be effective in the control of the red scale on citrus in Karnataka, Andhra Pradesh and Punjab (Krishnamoorthy, 1993; Tirumala Rao et al., 1954; Batra et al., 1987). Neem oil, pongamia oil, dicofol, sulfur, copper oxychloride and maneb were found safer to A. melinus and C. nigrita (Krishnamoorthy and Rajagopal, 1995).

\section{Aonidiella orientalis (Oriental yellow scale)}

The insect damages the plant by sucking sap, weakening it. The physical damage includes discoloration and deformation of leaves. Flowers and fruits fail to develop. When the insects feed on the fruits they are discolored and warped, reducing their value on the market. Aphytis sp was collected from $A$. orientalis infesting custard apple and banana but the parasitism did not exceed more than two per cent. The scale insect was found predated by the coccinellid Scymnus sp. and the green lacewing Mallada astur (Banks) on banana but the former was more abundant than the latter. A fungal pathogen Cladosporium sp. was also observed to infect $A$. orientalis to the extent of $20 \%$ in February. Aphytis sp. was known to parasitise up to $30 \%$ on Aonidiella orientalis infesting banana (Newstead) (Mani and Krishnamoorthy, 1996a).Oriental yellow scale had appeared in severe form on the fruits of sapota. C.nigrita was found actively feeding on the scales and able to clear all the scales in 2005 at IIHR Farm, Bangalore. In U.P., the aphelinid Ablerus aonidiellae sp.nr was recorded on $A$. orienralis infesting guava by Hayat (1974). Rajagopal and Krishnamoorthy (1996) indicated the parasitoid Comperiella bifasciata Howard and the predator Chilocorus nigrita as potential biological control agents. Encarsia citrina occurred naturally, producing levels of up to $80 \%$ parasitism, and was also therefore important in the biological control of A. orientalis (Elder et al., 1998).

\section{Aulacaspis tubercularis}

The white scale, Aulacaspis tubercularis Newstead was first reported on mango in India by Ayyar (1929). The scale infestation was confined to the under surface of mango leaves. Nymphs and female scale insects suck the cell sap resulting in yellow specks on the upper surface of leaves. In fact, the application of insecticides had resulted in marked increase in the population of $A$. tubercularis due to elimination of its natural enemies (Viljoen and Villiers, 1987). A total of ten natural enemies were found attacking A. tubercularis infesting mango. Among them, Pteroptrix koebelei How (Aphelinidae). was the only parasitoid observed on A. tubercularis. Earlier three parasitoids viz., Aphytis sp., Encarsia sp. and P. koebelei were reported on A. tubercularis in India (CIBC, 1984)). The predators included Chilocorus circumdatus Sch., Chilocorus nigrita (Fab.), Rodolia amabilis Kapur, Pseudaspidimerus trinotatus (Thunberg) Motsch., Scymnus quadripunctata, Ortalia octopunctata Gorham, Cybocephalus sp., Triommata coccidivora (Felt) and Mallada boninensis (Okamoto) (Mani and Krishnamoorthy, 1998a).

The field study revealed that the population of the scale was $39.50 / \mathrm{cm}^{2}$ in September'95 which had declined in the subsequent months. The initial sampling itself in September revealed the natural parasitisation $(40 \%)$ by $P$. koebelei and the predation by local biotic agents. The per cent parasitism went up to 96.61 . The activity of the parasitoid was found high in November'95 as 710.75 adults of $P$. koebelei had emerged from the scales infesting a single mango leaf. Among the predators, only C. nigrita, C. circumdatus, $P$. trionotatus, $S$. quadripunctata were found commonly associated with the mango scale. The population of the mango scale was not significantly affected by the predators and the rainfall. The multiple regression equation fitted with biotic agents and weather parameters to predict the scale population and it is concluded that the decline in the population of $A$. tubercularis was mainly due to the activity of the parasitoid. P. koebelei and also the weather 
parameters like minimum temperature and humidity (Mani and Krishnamoorthy, 1998a).

\section{Aspidiotus destructor}

Aspidiotus destructor Signoret is a highly polyphagous armoured scale and it is known to cause damage to mango. The scale insect is usually found in densely massed colonies on the lower surfaces of leaves, except in extremely heavy infestations where it may be present on both sides. Infestations are typically associated with yellowing of the leaves in areas where the scales are present. The yellowing is caused by the removal of sap by the sucking mouth parts and the toxic effects of the saliva that kills the surrounding tissues at the feeding site. Aphytis chrysomphali (Mercet), Aneristus ceroplastae How., Chrysonotomia sp. Comperiella bifasciata How., Chartocerus sp. Thompsonisca desantisiellus Shafee and Chilocorus nigrita Fabr. were recorded in UP. Among them T. desantiellus was the most commonly encountered in nature (Tandon and Srivastava, 1980). Predators play a significant part in limiting $A$. destructor populations. Chilocorus nigrita could be useful in the suppression of $A$. destructor.

\section{Florida red scale - Chrysomphalus ficus}

Chrysomphalus ficus (C. aonidum) is a leaf-infesting species, but in high-density infestations it may spread to fruits, stems and trunks, and may cause premature leaf and fruit drop and stem dieback. The scales appear as circular darks pots. An infestation appears as dark-purple to reddish-brown or black spots with paler margins, on both surfaces of shaded leaves of the host plant. Heavy infestations cause yellowing of the leaves, followed by defoliation of part or all of the host. C. aonidum prefers shade and is therefore most common in the lower part of the canopy. Chrysomphalus ficus Ashmead (= C. aonidum L). It is of minor importance on citrus in India. About 10 natural enemies were known to attack C. ficus in India. Microterys sp., Tetrastichus sp., Aphytis sp., A. mytilaspidis (Le Baron), Coelophora biplagiata Swartz., Chilocorus circumdatus, C. nigrita, Pharoscymnus horni and Nectria sp. were recorded on C. ficus in Karnataka (Singh,1993). C. nigrita gave substantial control of the scale in Seychelles (Bennet et al., 1976).

\section{Purple scale - Cornuaspis beckii}

Cornuaspis (= Lepidosaphes) beckii (Newman) sometimes becomes serious in South India. Scale infestation can be seen by the appearance of the purplish brown scale armour on stems, leaves and fruits of host plants. Nymphs and adults suck sap from the foliage and branches and spread to the fruits, causing disfiguration, which decreases market value. The areas surrounding the scale insects on leaves turn yellow and when severely infested the entire leaf may be discoloured prematurely. Heavy infestation can also lead to leaf fall and leaf and shoot malformation; and in extreme cases, host death. Microterys sp., Adelencyrtus femoralis Compere and Annecke, Aphytis sp., A. mytilaspidis, Tetrastichus sp., Coelophora biplagiata, Chilocorus circumdatus, C. nigrita, Pharoscymnus horni and Nectria sp. were reported on C. beckii (Anon., 1980). In Wynaad (Kerala), it was found infected by entomopathogenic fungus, Spherostelbe auranticola (Ramachandran, 1954).

\section{Yellow scale - Aonidiella citrina}

This species is morphologically close to Aonidiella aurantii (Maskell). A. citrina is a serious pest, mainly of citrus, causing leaf drop, twig die-back and fruit drop. Aphytis chrysomphali (Mercet), Physcus sp. nr. flaviventris (How.), Tetrastichus purpureus Cam. and Comperiella bifasciata (How.) from Namkum (Bihar) (Glover, 1935) and C. bifasciata from $A$. citrina Coquillett infesting citrus at Bombay and Pune. Pharoscymnus horni was considered to be the most promising predator in India (Compere, 1961).

\section{Phenacaspis manni}

Heavy infestation of this scale was observed on citrus in Tamil Nadu. Aphytis sp. and Encarsia sp. were recorded on P. manni (Green) (CIBC, 1984).

\section{Pinnaspis strachani}

Coccobius albipodus (Agarwal) and Arrenophagus chionaspidis Aurivillius were repoted on this scale Pinnaspis strachani (Cooley) infesting Citrus aurantifolia in Karnataka (CIBC, 1984).

\section{Pinnaspis aspidistrae}

In Andhra Pradesh, Eretmocerus sp, Azotus sp. and Adelencyrtus sp. were reared from Pinnaspis aspidistrae (Sign.) (Nagalingam, 1980).

\section{Latania scale- Hemiberlesia lataniae}

Hemiberlesia lataniae (Sign.) is becoming serious on grapevine Aphytis sp was found causing 14.6 to $20.6 \%$ parasitism during September-March. Release of Chilocorus nigrita helped to bring down the scale population on Bangalore blue in Karnataka (Mani, 2002).

\section{Pseudaulacaspis barberii}

Aphytis bengalensis Rosen \& Debach was recorded on P. barberii (Green) infesting mango leaves (Rosen and DeBach, 1986). 


\section{Pseudaulacaspis cokerelli}

Aphytis sankarani sp nr. was collected from the scale P. cokerelli (Cooley) (Rosen and DeBach, 1986).

\section{Aspidiotus orientalis}

The scale Aspidiotus orientalis (Newst.) was parasitised by Aphytis chrysomphali Mercet, Tetrastichus purpureus Cam. and Comperiella bifaciata How. (Nair, 1975)

\section{Soft Scale Insect species on fruit crops}

Soft scales differ from armoured scales in that they do not secrete a waxy covering that is separate from the body. Most soft scales produce a thin, glassy wax that does not obscure the colour or form of the female soft scale. The soft scales unlike hard scales excrete large amounts of honeydew. On this sticky excretion, a sooty mould develops, giving the stems or foliage a blackened appearance. Severe infestations, besides making the plant unattractive, will weaken it considerably even to the point of death. The second category belonging to family coccidae comprises of the soft scales belonging to the genera Coccus, Puvinaria, Chloropulvinaria, Saisettia, Parasaisettia, Vinsonia, Drephanococcus, Ceroplastes, Ceroplastodes, etc.

\section{Biological control of soft scales}

\section{Coccus viridis}

The adult female is shiny pale green with a conspicu- ous black, irregular U-shaped internal marking that is dorsally visible. The under surface of the leaf is preferred, and adult scales may be found in a line along both sides of the midrib and lateral leaf veins. Often they attack the young shoots. The green scale feeds from the phloem of the host plant and the scale insect excretes honeydew. Usually infestations are accompanied by sooty mold, a black fungus growth, which develops on honeydew excreted by the scale. Accumulations of sooty mold cause the infested plant to be unsightly. Sooty mould blackens the leaf and decreases photosynthesis. On fruit, sooty mold reduces the marketability of the fruit. When large populations are present yellowing, defoliation, reduction in fruit set and loss in plant vigour are caused.

\section{Citrus}

The soft green scale Coccus viridis (Green) (Homoptera, Coccidae)) has been reported as a pest of citrus (Singh and Rao, 1977; Tandon, 1985 ). Generally, the management of the green scale is limited to chemical control, but reinfestation of the scale is reported 35 days after insecticidal application (Singh and Rao, 1977). Alternatively, biological control of scales is found effective in the long run. Microterys sp., M. flavus (Howard), Anicetus annulatus Timberlake, Gyranusa sp., Tetrastichus sp., Coccophagus sp. Coccophagus cowperii Gir.,Coccophagus bogoriensis Kon., Cheiloneromyia javensis Gir., Chilocoru scircumdatus Sch., C. nigrita, Pharoscymnus horni Wse., Cryptolae-

Table 2. List of soft scales infesting fruit crops in India

\begin{tabular}{ll}
\hline Species & Host plants \\
\hline Ceroplastes floridensis Comstock & Apple, citrus, custard apple, fig, guava, mango, jack fruit, pomegranate, pear, plum \\
Ceroplastes rubens Maskell & Citrus, fig, jack fruit, mango, pear, date palm \\
Ceroplastes stellifer (Westwood) & mango \\
Ceroplastes rusci (Linn.) & Fig \\
Drepanococcus chiton Green & Ber and guava \\
Pulvinaria psidii Maskell & Guava, citrus, fig, jack fruit, jamun, litchi, loquat, mango sapota \\
Chloropulvinaria polygonata Green & Apple, grapes, mango, jamun, peach, citrus \\
Pulvinaria maxima (Green) & Grapevine, ber, citrus \\
Coccus acutissimus Green & Banana, ber, jack fruit, mango \\
Coccus discrepans Green & Banana, ber, citrus, fig, grapes, jamun, mango \\
Coccus hesperidum Linn & Citrus, papaya, mango \\
Coccus viridis (Green) & Citrus, sapota, guava, loquat and mango \\
Eulecanium tiliae (Linnaeus) & Almond, apple, apricot, cherry, loquat, peach, pear, plum \\
Hemilecanium imbricans (Green) & Mango,Fig \\
Parthenolecanium corni (Bouché) & Grapes \\
Parasaissetia nigra (Nietner) & Citrus, grapevine, guava, litchi \\
Saissetia coffeae (Walker) & Citrus, guava, fig \\
Saissetia oleae (Olivier) & Citrus, fig, guava, sapota, mango \\
Vinsonia stellifera Westwood & Mango, citrus, guava \\
\hline
\end{tabular}


mus montrouzieri Muls., Chrysopa sp., Verticillium lecanii (Zimm), Entomophthora sp., Hypocrella olivacea, Nectria sp., Podonectria sp., Fusarium sp. and Cladosporium sp. were recorded from Kodagu (Anon., 1980). Among them, Aneristus ceroplastae How. and Encyrtus lecanorium Mayr. Was known to cause up to $43 \%$ parasitism in the field (Tandon, 1985). Releases of C. nigrita helped in bringing down the population of $C$. viridis in citrus orchards (Tirumala Rao et al., 1954). The natural enemies were capable of suppressing $C$. viridis in undisturbed ecosystem. In acid lime, three coccinellid predators, Ch. circumdatus, Ch. nigrita, Cr. montrouzieri and an encyrtid parasitoid, Encyrtus lecaniorum Mayr. were observed on Coccus viridis. Due to the activity of natural enemies, the population of green scale declined from 300 scales per plant in July to negligible level from December onwards. The mean population of $C$. nigrita ranged from 2.10 to 16.90 per tree with a peak in August, 1994. Congregation of Chilocorus nigrita contained 2-6 pupae mainly on the leaf but in the case of C. circumdatus, up to 84 larvae were found pupating mainly on the trunk near the basin and sometimes on the ventral surface of the leaf. Both $C$. nigrita and C. circumdatus had highly positive and significant correlation with the population of the green scale. The population of $C$. montrouzieri ranged from 2.10 to 4.50 . Parasitism by E. lecaniorum ranged from 1.38 to 11.60 per cent (Mani and Krishnamoorthy, 1996; 1998b).

The white halo fungus fungus, Lenticillium (Verticilium, Cephalosporium) lecanii (Zimmerman) is the most common and apparently causes the highest percentage of mortality. At Kodagu in Karnataka, application of the fungal suspension of L. lecanii containing $16 \times 10^{4}$ spores $/ \mathrm{ml}$ sprayed just before the onset of rainy season was found to be effective against $C$. viridis infesting Coorg mandarin (Singh, 1985).

\section{Sapota}

Coccus viridis (Green) has recently become a major pest of sapota, Manilkara zapota in India (DhraraJothi and Tandon, 1991). Numerous species of predators, parasitoids and pathogens have been reported as natural regulatory factors of $C$. viridis infesting plantation crops and citrus (Narasimham, 1987; Reddy et al., 1997, Mani and Krishnamoorthy, 1997. Mani and Krishnamoorthy, 1998).

Field studies were conducted to determine the impact of natural enemies in the suppression of $C$. viridis on sapota in Karnataka. The green scale population declined from 134.74 in the first week of September to 0.54 by mid November. The population of the coccinellid predator C.nigrita ranged from 3.00 to 14.00 with a peak by mid September, while that of $C$. montrouziri from 1.2 to 4.5 .
The population green scale was positively correlated with the predators. The green scale was completely suppressed with the predators on sapota within three months (Mani and Krishnamoorthy, 1997).

In yet another field study, the population of green scale declined from 30.72 per leaf in May 2004 to 1.62 per leaf in March 2006. Two coccinellid predators Chilocorus nigrita (Fab.) and Cryptolaemus montrouzieri (Muls.) and one aphelinid parasitoid Coccophagus sp. were recorded on C. viridis. The parasitoid Coccophagus sp. was the dominant natural enemy causing up to $94.67 \%$ parasitism. Further, step-wise regression procedure employed to arrive at a multiple regression model showed that about $65.60 \%$ of the scale population could be predicted by one factor namely, parasitism by Coccophagus sp. it is concluded that the parasitism by Coccophagus sp. played a major role in regulating the population of the soft green scale infesting sapota (Mani et al.2008).

\section{Green shield scales}

Often referred to as mealy scales, they are pale yellowish green insects measuring up to 2.5-3 $\mathrm{mm}$. They cause damage by sucking the sap from leaves, stem and fruits. Heavy clustering of scale insects is usually seen under the lower surface of leaves. The scale insects excrete honeydew on which the fungus sooty mold develops thereby affecting the photosynthesis of the infested plants. Such affected plants appear to be sick and black. In the case of severely affected plants, growth and fruiting capacity are reduced. The green shield scales have high reproductive potential laying 500-700 greenish yellowish eggs in a cottony ovisac. After hatching, the young ones move freely to find a suitable spot on the plant to settle for further development. The young ones are called nymphs which are yellowish green in colour. Adult female scale secretes heavy waxy filaments at its posterior end forming ovisac in which eggs are laid. Eventually the cottony secretion nearby surrounds the scale which dies soon after oviposition and its shrunken body remains loosely attached as a lid on the top of ovisac. Females with ovisacs are often mistaken as mealybugs.

\section{Pulvinaria psidii}

\section{Guava}

The Green shield scale Pulvinaria ((=Chloropulvinaria) psidii Maskell is maor and regular pest of guava In the case of severely affected plants, growth and fruiting capacity are reduced (Easwaramoorthy and Jayaraj, 1977; Pawar et al., 1984). The green shield scales are very difficult to get controlled with conventional insecticides, since they have mealy covering and the eggs are protected with waxy fila- 
ments. Scymnus coccivora Ayyar, Cryptolaemus montrouzieri, Chilocorus nigrita, Cheilomenes sexmaculata (Fab.), Coccophagus cowperii Grlt., C. bogoriensis (Kow.) and Aneristus sp. were known to attack C. psidii (Anon., 1979; Puttarudriah and Channa Basavanna, 1957; Manjunath, 1986; Bennet and Hughes, 1959. Mani and Krishnamoorthy, 1990c). Agarwal et al. (1984) also reported Bothriophryne sp nr. pulvinariae Agarwal, Agarwal \& Khan and $B$. sp.nr. tachikawai Agarwal, Agarwal \& Khan from Chloropulvinaria sp. infesting guava trees in Rajasthan. Very often the local predators and parasitoids are not sufficient to suppress the population of the green shield scale effectively. The Australian ladybird beetle $C$. montrouzieri was found to be a voracious feeder on the ovisacs of $C$. psidii consuming about 3780 eggs (Mani and Krishnamoorthy, 1990c). The predator can be reared easily on the ripe pumpkins infested with the mealybugs in the laboratory (Chackoo et al., 1978). Releasing of C. montrouzieri helps to keep the green scales under perfect check.

A field study was conducted to prove its efficacy of releasing C. montrouzieri in the suppression of green shield scales. After checking the activity of ants, the predatory beetles were released@10 per tree either in the morning on the scale infested plants in the field. The population of the scale insects declined from 145.50/plant in April to 1.20 / plant in October The beetle feeds and breeds very well on the green shield scales and brings down the pest population effectively (Mani and Krishnamoorthy, 1990c). There was positive and significant association between $P$. psidii and $C$. montrouzieri in guava ecosystems (Verghese et al., 1998). Cephalosporium lecanii Zimm was found pathogenic to P.psidii (Easwaramoorthy and Jayaraj, 1977). Complete biological control of $P$. psidii was reported with Microterys kotinskyi Fullaway in Bermuda and other countries.

\section{Lemon}

Shoots and the leaves of lemon plants (Citrus limonL.) were found heavily infested with green shield scales. A mean of 42.50 scale ovisacs were present on a single shoot of $30 \mathrm{~cm}$ in length. Release of the Australian ladybird beetle, Cryptolaemus montrouzieri@30/plant declined from 42.50 in the second week of November to negligible numbers $(<1)$ by the third week of December (Mani and Krishnamoorthy, 1999a)

\section{Sapota}

The green shield scale Pulvinaria psidii suck the sap from leaves and tender shoots young sapota plants. The green shield scale was controlled by C. montrouzieri (Mani and Krishnamoorthy, 1997)

\section{Pulvinaria polygonata}

In recent years, scale insect Pulvinaria (Chloropulvinaria) polygonata has become serious pest on mango. The nymphs and adults of pest suck the sap of leaves and other tender parts which result in reduction of vigour of plants. Scale also excretes honeydew which facilitates in development of sooty mould on different plant parts.

Aneristus ceroplastae How, Metaphycus hederaceous sp. nr. Tetrastichus sp., Anicetus annulatus Timberlake, Nicostratus sp., and Anagyrus sp. were recorded from Malihabad (Singh, 1993). Coccophagus chloropulvinaiae sp nr (Hayat, 1974), Scymnus coccivora Ayyar (Ali 1964), Nephus regularis (Sinha and Dinesh, 1984), Coccophagus ceroplastae Howard (Das and Sahoo, A. K.2005 were also reported on P.polygonata in India. The parasitoids namely C. longifaciatus Timb. Coccophagus bivittatus Comp. C. nigricorpus sp. nr. Metaphycus helvolus sp. nr. and three predators viz. Cryptolaemus montrouzieri Muls. Mallada astur (Banks) and Spalgis epeus Westwood were obsereved on mango green shield scale around Bangalore.(Mani and Krishnamoorthy, 1998c).

The Australian ladybird beetle, Cryptolaemus montrouzieri is capable of consuming about 2400 eggs of the mango scale insect $P$. polygonata (Mani and Krishnamoorthy, 1998a). C. montrouzieri also feeds on the scales in the absence of egg mass. In the field, ants are commonly associated with the scale insects. They feed on the honeydew excreted by the scales, and ward off local parasitoids and predators of the scale insects. Hence, ants have to be controlled by the destruction of their nests and application of chlorpyriphos $(0.05 \%)$ to the ant holes. After checking the activity of ants, the predatory beetles are released either in the morning or evening on the scale infested plants in the field. A release rate of 5-10/small plant, 20-30/medium sized tree and 50/large sized tree is recommended for the suppression of the scales. The beetle feeds and breeds very well on the green shield scales and brings down the pest population within 2-3 months.

In a field study on the impact of $C$. montrouzieri, a mean of 128.40 scale insects/ shoot was observed on $16^{\text {th }}$ August 2011.The population of $C$. montrouzieri, ranged from 6.62 to 12.45 per shoot during the study period. The plants were cleared of almost of all the scale insects in the first week of October 2011 as compared to 192.25 scale insects /shoot in the check at same time.. In another field study on the impact of S.epeus, a mean of 72.86 scale insects/shoot was observed on $29^{\text {th }}$ August 2006 along with the appearance of the predator $S$. epeus. The population of 
S. epeus ranged from 3.40 to $8.45 \mathrm{~S}$. epeus / shoot during the study period. The plants were cleared of almost of all the green shield scale insects in the first week of October 2006. There was $97.20 \%$, and $95.27 \%$ reduction in the population of P. polygonata respectively was recorded within 45 and 35 days of appearance of $C$. montrouzieri and S. epeus respectively (Mani and Krishnamoorthy, 2016)

\section{Black/Nigra scale - Parasaissetia nigra}

Adult females of Parasaissetia (= Saissetia) nigra (Nietner) are dark brown to shiny black, elongate-oval, Nymphs are translucent-yellow /yellowish green and flat. The nigra scale feeds from the phloem of the host plant and may be found on leaves or twigs. Damage due to feeding of an individual scale is small. However, when large populations are present, yellowing, defoliation, reduction in fruit set, and a loss in plant vigor may result. Damage is due to secreting large amounts of honeydew which is colonized by sooty mould fungi, covering fruits and leaves by a thick black mass.

\section{Pomegranate}

Naturally occurring Scutellista caerulea (Fonscolombe) (= S.cyanea Mots.) causes heavy parasitism and effectively checks the scale insect in pomegranate orchards in Maharashtra (Jadav and Ajri, 1981)

\section{Custard apple}

In Karnataka, Custard apple shoots were found fully covered with P. nigra at the IIHR Farm, Bangalore during Jan-March Parasitism by Scutellista cyanea Motsch. (Pteromalidiae: Hymenoptera) was $18.50 \%$ in January which increased to $42 \%$ by March There was no fresh infestation of scales from June '97 onwards. (Mani and Krishnamoorthy, 1999b).

\section{Wax scale - Drepanococcus chiton}

Wax adheres tightly to the body of the female scale insect Drepanococcus (= Ceroplastodes) chiton (Green) and cannot be easily separated from it. Most soft scales produce a thin, glassy wax that does not obscure the color or form of the female soft scale. The scale insect infestation is confined to the lower surface of the leaves and shoots of guava plants. They suck the cell sap and excrete honeydew resulting in the development of sooty mold thereby interfering photosynthetic activity of guava plants.

\section{Guava}

Five parasitoids Anicetus ceylonensis Howard, Cephaleta brunniventris Motsch Diversinervus elegans Silvestri, Metaphycus helvolus (Compere), Philosindia sp. nr. longicornis Noyes and Hayat and four predators namely Chilo- corus nigrita, Cryptolaemus montrouzieri, Cheilomenes sexmaculata and Scymnus sp. are found to attack this scale (Mani, 1995). A field study was conducted to determine the impact of natural enemies in the suppression of wax scale on guava. The initial sampling revealed the natural parasitisation and predation of local biotic agents. By middle of November, A.ceylonensis, C. brunniventris and C. nigrita occurred in large numbers. A maximum of 16.30, 80.30 and 23.30 C. nigrita, A.ceylonensis and C. brunniventris were recorded as given in table. The percent parasitism went up to $98.00 \%$. The scale insect was suppressed mainly due to the activity of locally occurring natural enemies. The wax scale did not appear in the subsequent years (Mani, 1995). Dichlorvos $(0.10 \%)$ and endosulfan $(0.07 \%)$ and methyl demeton $(0.05 \%)$ showed the least residual toxicity to $A$. ceylonensis (Mani and Krishnamoorthy, 1997). Dichlorvos $0.10 \%$ and deltamethrin $0.005 \%$ were found to be safe to $C$. brunniventris (Mani and Krishnamoorthy, 1995).

\section{Ber}

The scale insect caused severe damage to ber in Karnataka. Severe infestation was observed on ber in May 1991 at IIHR Farm, Bangalore. Six parasitoids viz. Anicetus ceylonensis, Diversinervus elegans, Metaphycus helvolus, Philosinida longicornis and Cephaleta brunniventri and four coccinellid predators Chilocorus nigrita., Cryptolaemus montrouzieri, C. sexmaculata and Scymnus sp. were known to attack the scale in the field. Initial sampling in June did not indicated not much activity of natural enemies. The larval stage of predators Cryptolaemus montrouzieri, C. sexmaculata and Scymnus sp. were found feeding on the crawlers of the wax scale insect but the predatory population remained very low. The primary parasitoids Anicetus ceylonensis and Cephaleta brunniventris were found emerging in large numbers than the other parasitoids. $A$. ceylonensis was dominant reaching peak population of 47.60 in January 92. C. brunniventris was equally important and a maximum of 27.8 adults emerged in November 91.The other parasitoids had emerged in very small numbers . The parasitism by $A$. ceylonensis and $C$. brunniventris had increased from 5.60 in July 91 to 97.56 in January 92. Fresh scale infestation was not observed in the subsequent months in 1992.It is concluded that $A$. ceylonensis and $C$. brunniventris were able to check the scale population very effectively in India (Mani, 1995).

\section{Hemispherical scale - Saissetia coffeae}

Saissetia coffeae (Walk.) is a minor pest of citrus in India, and about 10 parasitoids and five predators were known to attack the scale. Aneristus ceroplastae, Anysis saissetiae (Ashm.), Cardiogaster fusciventris Motsch, Coccophagus flavescens How. and Encyrtus adustipennis Motsch were 
reported parasitising this species (Pruthi and Mani, 1945). Microterys sp., Anysis sp., Coccophagus sp., C. cowperii, Chilocorus circumdatus, C. nigrita, Pharoscymnus horni (Weise), C. montrouzieri, Chrysopa sp. and Lecanicilium lecanii were recorded on S.coffeae in Karnataka (Anon., 1980). The encyrtid Metaphycus helvolus Cam. gave complete control of the scale in Peru (Beingolea, 1969).

\section{Brown soft scale - Coccus hesperidum}

Coccus hesperidum Linn. was usually kept under check by natural enemies on citrus in UP in India. Physeus sp. n. oriensis Hussain \& Agarwal was reared from the scale on citrus (Husain and Agarwal, 1982). In March-April $1980,51.80 \%$ of the scales on papaya were found parasitised by Aneristus ceroplastae How. (Joshi et al., 1981).

\section{Plum Scales - Eulecanium tiliae \& Eulecanium tiliae coryli}

The coccids Eulecanium tiliae (L) \& Eulecanium tiliae coryli $(\mathrm{L})$ infest plum, apricot, almond, cherry, peach, plum and apple in H.P., Kashmir and U.P. The parasitoids Coccophagus sp., Blastothrix sericea (Dalman) and the fungus Rhinocladiella account for $90 \%$ mortality of the scales in H.P. (Sharma and Dogra, 1986).

\section{Hemilecanium imbricans}

Hemilecanium imbricans (Green) was initially low during the months of October to December and gradually increased, reached peak at the end of the April-May on mango and fig. Natural enemies like Chrysopid predator, Mallada desjardinsi (Navas) (=Mallada boninensis (Okamoto)) was recorded on $H$. imbricans from September to February throughout the season. Other predators found were Chilocorous nigrita (Fabricius), larvae of Eublemma amabilis (Moore) and an unidentified lepidopteran caterpillar (Patil et al.2016).

\section{Fig wax scale, Ceroplastes rusci}

The population intensity of Ceroplastes rusci (Linn.) was observed up to 23.33 insects/twig and up to 10.00 insect/leave. The maximum parasitisation by Tetrastichus ceroplastae (Gir.) was 67.6 and $71.20 \%$ in month of Mar' 2011 and 2012 respectively. While, parasitisation with Scutellista cyanea Motsch was find maximum 83.20 and $73.60 \%$ in the month of Sep' 2011 and 2012 respectively. These parasites were found to be efficient natural control of C. rusci (Kumar, 2013)

\section{REFERENCES}

Agarwal MM, Agarwal S, Khan MA. 1984. Some new chalcid parasites (Hymenoptera; Encyrtidae) recorded from India. J Ent Res. 8: 61-69.
Ali SM. 1964. Some studies on Pulvinaria cellulose Green, a mealy scale on mango in Bihar. Indian J Ent. 26: 361-362

Anon. 1979. Final Tech. Rep. of All India Co-ordinated Research Project on Biological control of crop pests and weeds. IIHR, Bangalore-89, 106 pp.

Anon. 1980. Annual report of All India Co-ordinated Research Project on Biological control of crop pests and weeds. PDBC, Bangalore-89.

Ayyar TVR. 1929. A contribution to our knowledge of South Indian coccidae (scales and mealybugs). Imperial Institute of Agricultural Research, Pusa, Bull. No.197, $72 \mathrm{p}$.

Bartlett BR. 1978. Margorodidae pp 132-136. In Clausen CP (Ed). Introduced parasites and predators of arthropod pests and weeds. A world Review. USDA, Agricultural Hand book No. 480.

Batra RC, Sandhu GS, Sohi AS. 1987. Outbreak of California red scale on citrus and suppression through coccinellid predators in the Punjab. Bull Ent. (New Delhi) 20: 161-62.

Beingolea GO. 1969. Biological control of citrus pests in Peru. Proc 1st Int Citrus Symp Riverside, Calif. 2: $827-838$.

Bennet FD, Hughes IW. 1959. Biological control of insect pests in Bermuda. Bull Ent Res. 50: 423-436.

Bennet FD, David Rosen P, Cochereau P, Wood BJ. 1976. Biological control of pests of tropical fruits and nuts. pp 359-387. In Huffakar CB.(Ed). Theory and Practice of Biological control. Messenger Academic Press, New York.

Chacko MJ, Bhat PK, Rao LVA, Deepak Singh MB, Ramanarayan EP, Sreedharan K. 1978. The use of ladybird beetle, Cryptolaemus montrouzieri for the control of coffee mealybugs. J Coffee Res. 8: 14-19.

CIBC, 1984. Survey for natural enemies of diaspine scale insects in South India. Final Technical Report of US. PL 480 Project, CIBC, Indian station, Bangalore 87 pp.

Compere H. 1961. The red scale and its natural enemies. Hilgardia 31: 173-278.

Das BK, Sahoo AK. 2005 Record of parasitoids of some scale and mealybug pests of mango from West Bengal, India. J Biol Cont 19: 71-72 
De Bach P. 1959. Ann Entomol Soc Amer. 55: 354-362.

Dhara Jothi B, Tandon PL. 1991. Present status of pest of sapota in Karnataka. Paper presented at National Seminar on optimisation of productivity and utilisation of sapota held at Navsar, India, 1991 Oct 18.

Easwaramoorthy S, Jayaraj S. 1977. Control of guava scale, Pulvinaria psidii Mask., and chili aphid, Myzus persicae (Sulz.), with Cephalosporium lecanii Zimm. and insecticides. Ind J Agric Sci. 43: 136-139.

Elder RJ, Smith D, Bell KL. 1998. Successful parasitoid control of Aonidiella orientalis (Newstead) (Hemiptera: Diaspididae) on Carica papaya L. Aust J Agric Sci. 37(1): 74-79.

Glover PM. 1935. An account of the occurrence of Chrysomphalus aurantii Mask and Laccifera lacca Kerr. on grape fruit in Ranchi district, chcota Nagpur with a note on the chalcidoid parasites of Aspidiotus orientalis Newst. J Bombay Nat Hist Soc. 38: 151-53.

Hayat M. 1974. Some Indian species of Aphelinidae with the descripyion of new Coccophagus (Hymenoptera: Chalcidoidea) J Nat History 8: 179-188

Hussain T, Agarwal MM. 1982. Studies on some aphelinid (Hym.:Chalcidoidea) parasites of hemipterous insects of India. J Bombay Nat Hist Soc. 79: 1:155-162.

Jadav SS, Ajri DS. 1981. A new record of Scutellista cynaeae Mots (Pteromalidae, Hymenoptera), an external parasite of Parasiassettia nigra (Nietner) on pomegranate in Maharashtra state. Indian J Ent. 43: 112.

Joshi JC, Rao PK, Rao BHKM. 1981. A new record of Aneristus ceroplastae Howard on brown soft scale Coccus hesperidium L. on a new host papaya from India. Entomon 6: 2:129-130.

Krishnamoorthy A. 1993. Bionomics and development of integrated management strategy for California red scale, Aonidiella aurantii (Maskell). Ph.D. Thesis, University of Agric. Sci., Bangalore, India.

Krishnamoorthy A, Rajagopal D. 1995. Comparative toxicity of pesticides to natural enemies of California red scale, Aonidiella aurantii (Maskell). Pest Mgmt Hort Ecos. 1: 2:71-79.
Kumar A. 2013. Fig wax scale, Ceroplastes rusci an emerging pest of Dalbergia sissoo and its parasitisation in India. Int J Curr Sci. 8: 106-114.

Mani M. 1995. Studies on the natural enemies of the wax scale Drepanococcus chiton (Green) (Homoptera, Coccidae) on ber and guava in India. Entomon 20: 55-58.

Mani M. 2002. Recent trends in biological control of fruit crop Pests in India. pp 41-57. In Ignacimuthu, Sen A (Eds). Strategies in Integrated Pest Management. Phoenix Publishing House Pvt. Ltd., New Delhi.

Mani M, Krishnamoorthy A. 1990. Evaluation of the exotic predator Cryptolaemus montrouzieri Muls. (Coccinellidae, Coleoptera) in the suppression of green shield scale Chloropulvinaria psidii (Maskell) (Coccidae, Homoptera) on guava. Entomon 15: 45-48.

Mani M, Krishnamoorthy A. 1995. Toxicity of pesticides to the wax scale parasitoid, Cephaleta brunniventris. Indian J Pl Prot. 22(1): 108-109.

Mani M, Krishnamoorthy A. 1996. Discovery of the coccinellid predator, Chilocorus circumdatus on the green scale, Coccus viridis. Entomon 21(3\&4): 295-296.

Mani M, Krishnamoorthy A. 1997. Biological suppression of the soft green scale, Coccus viridis (Green) and the green shield scale, Chloropulvinaria psidii (Maskell) on sapota. Pest Mgmt Hort Ecos. 3(2): 114-116.

Mani M, Krishnamoorthy A. 1998a. Studies on the natural enemies of the mango scale, Aulacaspis tubercularis Newstead (Diaspididae, Homoptera). Paper presented in the National Symposium on Mango Production and Export, Lucknow. June 25-27.

Mani M, Krishnamoorthy A. 1998b. Suppression of the soft green scale Coccus viridis (Green) on acid lime in India. Proc I Natl Symp Pest Mgmnt Hort Crops. Bangalore, 1998. p. 210-212.

Mani M, Krishnamoorthy A. 1998c. Biological control studies on the mango green shield scale, Chloropulvinaria polygonata (Ckll.) (Homoptera: Coccidae) in India. Entomon 23(2): 105-110.

Mani M, Krishnamoorthy A. 1999a. Suppression of green shield scale, Chloropulvinaria psidii (Maskell) with Australian ladybird beetle on lemon. Insect Env. 4(4): 116-117. 
Mani M, Krishnamoorthy A. 1999b. The nigra scale Parasaissetia nigra and its natural enemies on custard apple in Karnataka. Insect Env. 5 (1): 20.

Mani M, Krishnamoorthy A. 2001. Managing scale insects on fruit crops. Indian Hort. 46(3): 4-7.

Mani M, Gangavisalkshi PN, Krishnamoorthy A, Venugopalan R. 2008. Role of Coccophagus sp. in the suppression of soft green scale Coccus viridis (Green) (Coccidae; Homoptera) on sapota. Biocontrol Sci Tech. 18(8): 721-725.

Manjunath TM. 1986. Recent outbreaks of mealybugs and their biological control in resurgence of sucking pests. pp.249-253.In Jayaraj S (Ed). Proc Natl Symp, TNAU, Coimbatore.

Masoodi MA, Trali AR, Bhat AM, Tikku RK, Nehru KK. 1989. Establishment of Aphytis sp. proclia of San Jose scale in Kashmir. Indian J Pl Prot. 17: 71-73.

Nagalingam B. 1980. New record of three aphelinid and three encyrtid parasites on citrus scale insect Pinnaspis aspidistrae (Sign.) Curr Res. 9: 191-92.

Nair MRGK. 1975. Insects and mites of crops in India. ICAR, New Delhi, 185 pp.

Narasimham AU. 1987. Scale insects and mealybugs on coffee, tea and cardamom and their natural enemies. $J$ Coffee Res. 17: 7-13.

Patil RR, Hugar PS, Benagi VI, Mathad JC. 2016. Status and incidence of scale insect, Hemilecanium imbricans (Green) (Coccidae: Homoptera) on mango and other host plants in few districts of Karnataka. J Exptl Zool. India 19: 883-89.

Pruthi HS, Mani MS. 1945. Our knowledge of the insects and mites pests of citrus in India and their control. ICAR monograph No. 16, 42 pp.

Puttarudriah M, Channabasavanna GP. 1957. Beneficial Coccinellidae of Mysore II. Mysore Agric J. 32: 4-19.

Rajagopal D, Krishnamoorthy A. 1996. Bionomics and management of oriental yellow scale, Aonidiella orientalis (Newstead) (Homoptera:Diaspididae): An over view. Agricultural Reviews (Karnal) 17(3/4): 139-146.

Rao VS, Rao VP. 1960. Introduction of Prospaltella perniciosi for the control of San Jose scale in India and Pakistan. FAO Pl Prot Bull. 8: 120-123.
Rao VP. 1969. India as a source of natural enemies of pests of citrus. pp 1-16. In Ramachandran TS. Proc First Intl Symp. Madras Agric Dept Bull. In Proc First Intl Citrus Symp. 2:785-792.

Ramachandran TS. 1954. Insect pests of orange in Madras state. Bull Madras Agric Dept. 16 pp.

Rawat US, Thakur JN, Pawar AD. 1988. Introduction and establishment of Chilocorus bijugus Mulsant and Pharoscymmus flexibilis Mulsant, predatory beetles of San Jose scale in Thanedhar areas of Himachal Pradesh, Curr Sci. 57: 1250-1251.

Reddy KB, Bhat PK, Naidu R. 1997. Suppression of mealy bugs and green scale infesting coffee with natural enemies in Karnataka. Pest Mgmt Econ Zool. 5: 119-121.

Rosen D. 1990. World Crop Pests. 4B. Armoured scale insects: Their biology, natural enemies and control. Amsterdam, Netherlands: Elsevier Science Publishers, 688 pp.

Rosen M, DeBach P. 1986. Three new species of Aphytis (Hymenoptera: Aphelinidae), parasites of Pseudaulacaspis spp. (Homoptera: Diaspididae) in India and Australia. Entomophaga 31: 139-51.

Sahai B, Joshi LD. 1965. Bionomics and biological control of San Jose scale (Quadraspidiotus perniciosus Comstock) in U.P. Punjab Hort J. 5: 37-43.

Sharma JP, Dogra GS. 1986. Studies on the control of plum scale Eulecanium sp.nr. tiliae (L) (Homoptera Coccidae) through chemicals and natural enemies. Indian J Ent. 48: 258-268.

Singh SP. 1985. Biological control of insect pests of horticulture. Proc Natl Sem Entomoph Ins., Calicut, pp. 221-231.

Singh SP. 1993. Biological control of pests. pp 15911616. In Chadha KL, Pareek OP. (Eds). Advances in Horticulture. Malhotra Publishing House, New Delhi.

Singh SP. 2000. Biological control in horticultural crops. Indian Hort. 45(1): 54-60.

Singh SP, Rao NS. 1977. Effectiveness of different contact insecticides against green scale, Coccus viridis (Green) (Coccidae, Homoptera) on citrus. Pesticides 11: 33-36. 
Sinha PK, Dinesh DS. 1984. A report on the coccids (Hemiptera:Coccoidea), their host plants and natural enemies in Bhagalpur. Biol Bull India 6: 7-12.

Tandon PL. 1985. Spatial distribution, sampling technique and population dynamics of citrus green scale Coccus viridis (Green) on mandarin, Ph.D. Thesis, UAS, Bangalore, 278 pp.

Tandon PL, Srivastava RP. 1980. New records of parasites and predators of important insect pests of mango. Entomon 5: 243-44.

Thakur JN, Rawat US, Pawar AD. 1989. Investigations on the occurrence of natural enemies of San Jose scale, Quadraspidiotus perniciosus Comstock (Hemiptera:
Coccidae) in Jammu and Kashmir and Himachal Pradesh. Entomon 14: 143-146

Tirumala Rao V, David AL, Mohan Rao KR. 1954. Attempts at the utilisation of Chilocorus nigritus Fab. (Coleoptera, coccinellidae) in the Madras State. Indian J Ent. 16: 205-9

Viljoen HM, Villiers EA. 1987. Effectiveness of fenvalerate and monocrotophos against the mango scale, Aulacaspis tubercularis Newstead. Information Bulletin, Citrus and Subtropical Fruit Research Institute, South Africa, No.173, pp 19-23. 